\title{
Gender Based Violence and Reproductive Health of Indigenous Women in Mexico
}

\author{
Claudia Elizabeth Gonzalez Amaya, Arun Kumar Acharya, José María Infante Bonfiglio \\ Universidad Autónoma de Nuevo León, San Nicolás de los Garza, México \\ Email: lizi.amaya@gmail.com, arun.kumara@uanl.mx, jose.infanteb@uanl.mx
}

Received 13 April 2016; accepted 2 July 2016; published 5 July 2016

Copyright (C) 2016 by authors and Scientific Research Publishing Inc.

This work is licensed under the Creative Commons Attribution International License (CC BY). http://creativecommons.org/licenses/by/4.0/

(c) (i) Open Access

\begin{abstract}
Millions of girls and women suffer from violence and its consequences because of their sex and their unequal status in society. Gender-based violence is a serious violation of women's human rights. Yet little attention has been paid to the serious health consequences of abuse and the health needs of abused women and girls. Women who have experienced physical, sexual, or psychological violence suffer a range of reproductive health problems, often in silence. They have also poorer physical and mental health, suffer more injuries, and use more medical resources than non-abused women. Thus, in this paper we have tried to explore how gender-based violence impact on the reproductive health of indigenous women in Mexico. For this study, we have interviewed 250 indigenous women in Monterrey Metropolitan Region of Mexico.
\end{abstract}

\section{Keywords}

Gender Based Violence, Reproductive Health Problem, Injuries, Indigenous Women, Mexico

\section{Introduction}

The World health Organization estimates that 35 percent of women worldwide have experienced either physical and/or sexual intimate partner violence or sexual violence by a non-partner at some point in their lives. However, some national studies show that up to 70 percent of women have experienced physical and/or sexual violence from an intimate partner in their lifetime (WHO, 2013). In the years 1993, the United Nations Declaration on the Elimination of Violence against Women defined gender based violence (GBV) as: any act of violence that resulted in, or was likely to result in, physical, sexual or psychological harm or suffering to women, including threats of such acts, coercion or arbitrary deprivations of liberty, whether occurring in public or private life (United Nations, 1993). The term "gender-based violence" (GBV) is used to describe violent acts targeting individuals based on their sex, gender identity, or their perceived adherence to gender norms. GBV consists of a 
wide range of physical or psychological abuses or threats including sexual exploitation, coercion and rape, and forced or early marriage, among others (United States Agency for International Development, 2014).

Research conducted on gender-based violence has considered as a pervasive public health problem that has implications for health policies and programs around the world (Population Reference Bure, 2010). The study of world Health organization indicates that nearly $35 \%$ of women worldwide have experienced either physical and/or sexual intimate partner violence or non-partner sexual violence in their lifetime (WHO, 2016). According to sociological approach theories, gender violence is a phenomenon that exists because there is no strong societal prohibition against it or because there are functional reasons for its existence in a particular setting (Levinson, 1989; Erchak \& Rosenfeld, 1994 in Cunningham et al., 1998). For example, the social learning theory (Bandura, 1978) describes that individuals observe how their parents behave toward each other and imitate during subsequent time period. Bandura suggests that violence can be learned from three primary sources: family, culture and subculture and the media.

On the other hand, gender-based violence (GBV) is a global public health epidemic that has no boundaries. It is one of the most common forms of violence and includes physical, sexual, emotional and economic violence, also it cuts across societies, classes, races, religions and ethnicities, affecting an estimated one in three women in the course of her lifetime (WHO, 2013). Evidence suggests that at least 60 percent of women globally are exposed to reproductive health problems related to gender based violence (UNFPA, 2013). According to the International Conference on Population and Development (ICPD) and its program of Actions, the gender based violence as an important component for reproductive health issues, thus ICPD define, it as a complete state of physical, mental and social wellbeing in all matters relating to the reproductive system at all stages of life and no merely the absence of infirmity. Implicitly, reproductive health enables people to have a satisfying and safe sex life and that they have the capacity to reproduce and the freedom to decide if when and how often to do so (WHO, 2013).

However, during the last two decades, globally many polices at regional and international have been formulated to eradicate the gender based violence targeting women, regardless of all policies, GBV continues to increases at different level. For example, it has been noted that, globally 1 in every 3 women still experience physical or sexual violence mostly by an intimate partner (WHO, 2013). According to Mexican census data, 47 percent of women (15 years and more) have been suffered violence by their intimate partner. However, in the case of indigenous women it rose to 62 percent (INEGI, 2013). Evidence at global level (UNFPA, 2013) reflects that, gender based violence has a significant impact on the health and well-being of women both in the immediate and longer term. Exposure to violence leads to poorer physical health overall compared with women who have not experienced violence, and it increases the risk of women developing a range of health problems (WHO, 2013). A study in Brazil revealed that 13 percent of deaths respectively among women aged 15 - 49 years were a result of physical violence perpetrated by male sexual partners (Diniz \& D'Oliveira, 1998). similarly, in India according to NFHS 3 data about 40 percent of ever married women of age group 15-49 have experienced at least one of the forms of spousal violence i.e. physical or sexual or emotional and 30 percent of them have reported any kind of reproductive health problem (Varma et al., 2007). A survey conducted in South Africa showed that women who were sexually abused by their partner were 48 percent more likely to be infected with HIV than those who were not (UNAIDS, 2010). Thus, considering the above discussion, the main objective of this study is to analyze the impact of gender-based violence on the reproductive health of indigenous women in Mexico.

\section{Literature Review on Gender Based Violence and Health Consequence}

Violence can occur during any phase of women's lives. Many women experience multiple episodes of violence that may start in the prenatal period and continue through childhood to adulthood and old age (see Table 1). A global synthesis of lifetime prevalence data on intimate partner violence reveals high prevalence rates among young women, indicating that violence starts early in women's relationships. Among ever-partnered women aged 15 - 19 years, 29\% have experienced physical and sexual violence by an intimate partner. Prevalence reaches its peak in the age group of 40 - 44 years (37.8\%) and declines for women aged 50 years and older (WHO, 2013).

Above Table 1, illustrate that women faces violence in different phases of their lifecycle, which make it understand the cumulative impact of violence, especially in terms of its long-term effects on the lives and health of women. Violence experienced in one phase can have long-term effects that predispose the survivor to severe secondary health risks, such as suicide, depression, and substance abuse (Heise et al., 1994). Health conse- 
Table 1. Stages of violence faced by women in their lifecycle.

\begin{tabular}{cl}
\hline Life stages & \multicolumn{1}{c}{ Violence faced } \\
\hline Before birth & Sex selective abortion \\
Infancy & Female infanticide, emotional and physical abuse, differential access of food and medical care \\
Adolescences & Forced marriage, sexual abuse, sexual harassment, forced prostitution, trafficking etc. \\
Adulthood & Marital rape, intimate partner violence, psychological abuse, forced abortion etc. \\
Old age & Physical abuse \& violence, emotional violence, economic violence, isolation etc.
\end{tabular}

Source: Heise et al., 1994.

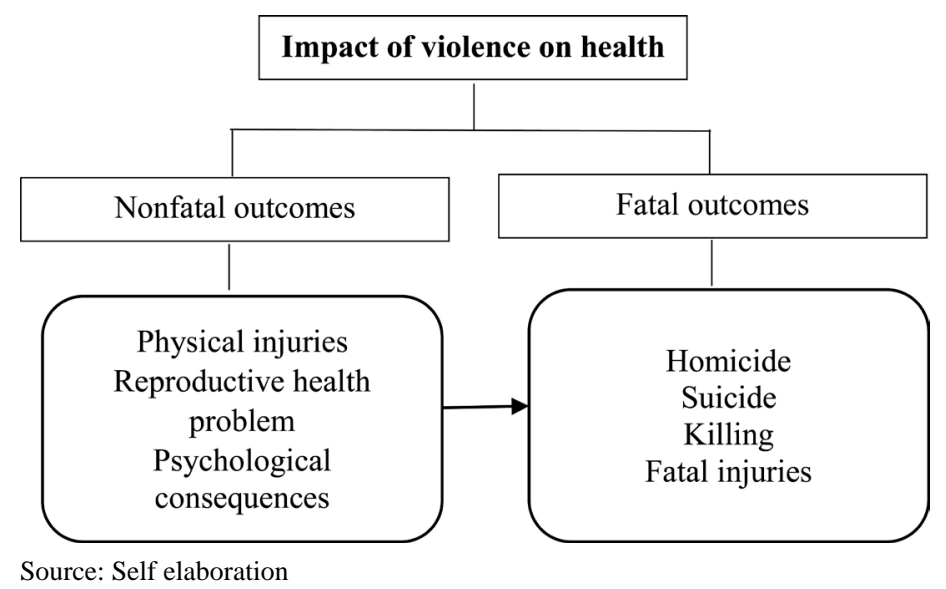

Figure 1. Violence and its impact on health.

quences of gender-based violence can be both, immediate and acute as well as long lasting and chronic; indeed, negative health consequences may persist long after the violence has stopped. The more severe the level of violence, the greater the impact will be on women's health. Furthermore, exposure to more than one type of violence (physical and sexual) and/or multiple incidents of violence over time tends to lead to more severe health consequences (see Figure 1).

A recent study published by the WHO in 2013 systematically reviewed studies providing data on health effects of physical and sexual intimate partner violence and non-partner sexual violence against women. The report stated that globally, 38 percent of all murders of women are reportedly committed by intimate partners. Similarly, out of all women who experienced physical and/or sexual violence by an intimate partner, 42 percent experienced injuries. On the other, the study also indicated that compared to women who have not experienced partner violence, women survivors of such violence face a 16 percent higher risk of having a low-birth weight baby, are more than twice as likely to have an induced abortion, and are more than twice as likely to experience depression (WHO, 2013).

The study of Popa (2009) on domestic violence and its consequences on health, stated that violence has deep and can influence more than health status and individual well, namely the "health" of the entire community. A woman who lives in a violent relationship loses confidence in itself and in its ability to participate in life. Mistreated women present difficulties of access to information and the existing health services. Consequences of domestic violence may persist long after the act of violence itself is consumed, and repercussions in time of the different types and multiple episodes of violence are cumulative. The violence is even more serious, the impact on physical and mental health is more profound.

A study conducted by Lozano (1999) on the health impact of domestic violence on women in Mexico City indicates that women who have faced marital violence suffered from different kinds of physical, psychological, and sexual consequences of non-fatal intentional injuries.

\section{Data and Methods}

The present study is based on quantitative data collected during the months of July and September 2015 in the 
Monterrey Metropolitan Region, Mexico. Monterrey is the capital city of Nuevo León state and situated on north of Mexico. The state also share international border with USA. Monterrey is also known as financial capital of Mexico due to larger concentration of multinational industries. In this regards the city also one of favorable destination of migration both national and international due to higher wage rates as well as availability of employment both in secondary and tertiary sectors. Moreover, there are also higher demands of domestics servants, which mainly fill-up by indigenous migrants (Pérez, 2014). Considering the number of migrants, for this study a total $\mathrm{N}=250$ indigenous women age of 15 to 40 were interviewed. A multi-stage random sampling procedure was used to identify and selected respondents. All women were interviewed in Alameda Park ${ }^{1}$ and mainly on weekend. The questionnaire was constructed in Spanish language, which included questions on socio-economic and demographic information, working and lining condition and reproductive health status of respondents. Once we collected the information, it was process in SPSS program for the analysis.

\section{Results}

\subsection{Sociodemographic Characteristics of Indigenous Women}

As we have stated earlier, for the present study we have interviewed 250 indigenous women in the Monterrey Metropolitan Region of Mexico. From the Table 2 we can observe that 45 percent of these are belongs to the age groups of 21 - 30 years and nearly 30 percent are belongs to 15 to 20 years old and around 26 percent of women belongs to a age groups of 30 years and more. With regards to their marital status, we can see that nearly 68 percent of women are currently married, 17 percent are unmarried and living with their boyfriend and 15 percent of women are divorced or separated. When we analyzed the educational status of indigenous women nearly 75 percent indigenous women are educated up to primary level, 15 percent of women responded that they studied up to secondary level, however, data indicates that nearly 5 percent women are illiterate (see Table 2).

On the other hand, when we analyzed the occupation of indigenous women, results indicates that nearly 63 percent women employed as domestic servants, whereas 16 percent works as waiter in restaurants, nearly 12 percent women said they are technical workers, also some women (7 percent) are nurses. Thus, we can observe from the results that majority of women works as domestic servants in the city. With relation to their income, our analysis indicates that nearly 73 percent of women earned less than 5000 pesos monthly; however, 19 percent of indigenous women indicate that their monthly income is 5000 to 10,000 pesos and only 8 percent indigenous women said they earned more than 10,000 pesos every month (see Table 3).

\subsection{Impact of Violence on Indigenous Women's Health}

In the case of Mexico, according to INEGI statistics, 63 percent of Mexican women over 15 years of age have experienced some form of gender violence, which could include physical, sexual, emotional, or psychological violence as well as economic forms of abuse such as discrimination in the workplace. Perpetrators of violence

\begin{tabular}{|ccc}
\hline Table 2. Indigenous women and their sociodemographic background. \\
\hline Background characteristics & Percentage & Number \\
\hline Age group & & \\
$15-20$ & 28.8 & 72 \\
21 - 30 & 45.2 & 113 \\
30 - 40 & 16.0 & 40 \\
More than 40 years & 10.0 & 25 \\
Marital status & & \\
Unmarried/living with partner & 17.2 & 43 \\
Currently married & 67.6 & 169 \\
Separated and divorced & 15.2 & 38 \\
Educational status & & \\
Illiterate & 4.8 & 12 \\
Up to primary & 74.4 & 186 \\
Up to secondary & 15.2 & 38 \\
Bachelor degree and more & 5.6 & 14 \\
\hline
\end{tabular}

\footnotetext{
${ }^{1}$ Alameda Park is situated in down town of Monterrey.
} 
against women are strangers or people known to the victims, as in the case of abuse between partners, which is usually where physical violence occurs, according to INEGI. Economic abuse and economic control of women also often happens within a partnership or marriage. However, when we analyze the violence against indigenous women, it has observed that nearly 62 percent of indigenous women suffer gender based discrimination and violence (Díaz, 2012). Taking into consideration, the above discussion, in the following table we have analyzed the violence faced by the indigenous women during the last one year. Our analysis indicates that nearly 68 percent indigenous responded that they have faced different kinds of violence by their partner. Similarly, when we asked about the type of violence they faced, it has seen that nearly 61 percent reported physical violence, 25 percent said they have faced sexual violence by their partner and 67 percent said they have faced emotional violence (see Table 4).

The above table indicates the violence faced by indigenous women by their partner, however as we have seen on our earlier discussion, the violence has a direct impact on women's health. Taking into consideration the above hypothesis, during the interviews, we have asked our respondents are they faced any kind of reproductive health problem due to violence. With regard to this assumption, our analysis indicates that, 63 percent of women reported physical injuries, 36 percent said irregular menstrual cycle, nearly 66 percent said abdominal pain, 55 percent reported excessive vaginal discharge, 49 percent said pain during urination, 54 percent indicated frequent urination and 49 percent said bad smell discharge. However, our data indicates that nearly 7 percent women suffered from premature labour pain and nearly 5 percent had stillbirth (see Table 5).

Table 3. Occupational distribution of indigenous women in Monterrey.

\begin{tabular}{ccc}
\hline Occupation & Percentage & Number \\
\hline Employment & & \\
Domestic servants & 62.8 & 157 \\
Waiter in restaurants & 16.4 & 41 \\
Technical workers & 11.6 & 29 \\
Nurses & 7.2 & 18 \\
Others & 2.0 & 5 \\
& & 182 \\
Income (monthly) & 72.8 & 48 \\
Less than 5000 pesos & 19.2 & 20 \\
5000 to 10,000 pesos & 8.0 & \\
More than 10,000 pesos & & \\
\hline
\end{tabular}

Table 4. Indigenous women faced violence by their partner.

\begin{tabular}{ccc}
\hline Violence faced by women & Percentage & Number \\
\hline Yes & 67.6 & 169 \\
No & 32.4 & 81 \\
Type of violence faced & & \\
Physical & 60.8 & 152 \\
Sexual & 25.2 & 63 \\
Emotional & 66.8 & 167 \\
\hline
\end{tabular}

Table 5. Percentage distribution of indigenous women who suffered reproductive health problems as a result of violence.

\begin{tabular}{ccc}
\hline Reproductive health problem & Percentage & Number \\
\hline Physical injuries & 63.3 & 107 \\
Irregular menstrual cycle & 36.0 & 90 \\
Abdominal pain & 65.6 & 111 \\
Excessive vaginal discharge & 55.0 & 93 \\
Pain during intercourse & 49.1 & 83 \\
Burning sensation during urination & 27.2 & 46 \\
Frequent urination & 53.8 & 91 \\
Bad smell discharge & 49.1 & 83 \\
Miscarriage & 18.3 & 31 \\
Premature labour pain & 6.5 & 11 \\
Stillbirth & 4.7 & 8 \\
\hline
\end{tabular}




\section{Conclusion}

The study of UNFPA and WAVE (2014) on Strengthening Health System Responses to Gender based Violence in Eastern Europe and Central Asia stated that; Gender based violence seriously affected all aspects of women's health - physical, sexual and reproductive, mental and behavioural health. Health consequences of this violence can be both, immediate and acute as well as long lasting and chronic; indeed, negative health consequences may persist long after the violence has stopped. The more severe the level of violence, the greater the impact will be on women's health. Furthermore, exposure to more than one type of violence (physical and sexual) and/or multiple incidents of violence over time tends to lead to more severe health consequences (WHO 2002, Johnson and Leone 2005, in UNFPA and WAVE 2014). The World Bank estimates that gender based violence accounts for 5 percent of the healthy life years of life lost to women age 15 to 44 in developing countries (World Bank, 1993, in Heise et al. 1994).

In the case of Mexico, nearly 50 percent of women reported violence were faced by their partner, however, when we analyzed in the case of indigenous women, it has observed that nearly 7 out of 10 women were affected by the gender violence by their partner. Similarly, our study indicated that, indigenous women experienced different kinds of physical, sexual and emotional violence by their intimate partner. On our analysis on impact of violence on reproductive health, we find that indigenous women have reported different kinds of reproductive health problems; however, it has also seen that women who are pregnant and suffer violence by their partner observe premature labour pain and stillbirth. Thus, here we can conclude that these forms of violence have negative impact on women's reproductive health, yet a culture of silence as well as lesser inclusion of indigenous groups in implementation and enforcement of public policies has caused an imbalance on Mexican society.

\section{References}

Bandura, A. (1978). Social Learning Theory. Englewood Cliffs, NJ: Prentice-Hall.

Cunningham, A., Jaffe, P. G., Baker, L., Dick, T., Malla, S., Mazaheri, N., \& Poisson, S. (1998). Theory-Derived Explanations of Male Violence against Female Partners: Literature Update and Related Implications for Treatment and Evaluation. London: London Family Court Clinic. http://www.lfcc.on.ca/maleviolence.pdf

Díaz, A. (2012). Las indígenas viven violencia estructural en el interior de sus propias comunidades. Mexico City: La Jornada. http://www.jornada.unam.mx/2012/08/05/politica/011n2pol. 09/03/2016

Diniz S. G., \& D’Oliveira, A. F. (1998). Gender Violence and Reproductive Health. International Journal of Gynaecology and Obstetrics, 63, 33-42.

Erchak, G., \& Rosenfeld, R. (1994). Societal Isolation, Violent Norms, and Gender Relations: A Reexamination of Levinson's Model of Wife Beating, Cross-Cultural Research, 28, 111-133. http://dx.doi.org/10.1177/106939719402800202

Heise, L. L., Pitanguy, J., \& Germain, A. (1994). Violence against Women: The Hidden Health Burden. World Bank Discussion Papers; No. WDP 255. Washington DC: The World Bank.

http://documents.worldbank.org/curated/en/1994/07/442273/violence-against-women-hidden-health-burden

Instituto Nacional de Estadística y Geografía (INEGI) (2013). Panorama de violencia contra las mujeres en el Estado de México, 2006. Mujeres y hombres en el estado de México. Estadísticas sobre desigualdad de género y violencia contra las mujeres. Aguascalientes: Instituto Nacional de Estadística y Geografía.

http://www.inegi.org.mx/prod_serv/contenidos/espanol/bvinegi/productos/estudios/sociodemografico/mujeresrural/2011/7 02825048327.pdf

Levinson, D. (1989). Family Violence in Cross-Cultural Perspective. Newbury Park, CA: Sage.

Lozano, R. (1999). The Impacts of Domestic Violence on Health: Mexico City. In Morrison and Biehl (Eds.), Too Close to Home: Domestic Violence in the Americas (pp. 81-101). Washington DC: Inter-American Development Bank.

Pérez, P. (2014). Los indígenas en Monterrey. 10 April 2014. http://www.sexenio.com.mx/nuevoleon/articulo.php?id=22094

Popa, M.-S. (2009). Domestic violence and Its Consequences on Health. Journal Management in Health, No 3. http://journal.managementinhealth.com/index.php/rms/article/viewFile/28/96

Population Reference Bureau (2010). Gender-Based Violence: Impediment to Reproductive Health. http://www.prb.org/igwg_media/gbv-impediment-to-RH.pdf

United Nations (1993). Declaration on the Elimination of Violence against Women. New York: General Assembly. http://www.un.org/documents/ga/res/48/a48r104.htm

United Nations Population Fund (UNFPA) (2013). The Role of Data in Addressing Violence against Women and Girls. New 
York: UNFPA. http://www.unfpa.org/sites/default/files/resource-pdf/finalUNFPA_CSW_Book_20130221_Data.pdf

UNFPA and WAVE (2014). Strengthening Health System Responses to Gender based Violence in Eastern Europe and Central Asia: A Resource Package. Vienna: UNFPA Regional Office for Eastern Europe and Central Asia, Turkey and WAVE Network and European Info Centre against Violence. http://www.health-genderviolence.org/sites/default/files/download/WAVE-UNFPA\%20English.pdf

United Nations Programme on HIV and AIDS (UNAIDS) (2010). Global Report Fact Sheet: Sub-Saharan Africa. Geneva: UNAIDS.

United States Agency for International Development (2014). Equal Rights, Equal Justice Toolkit for Addressing Gender-Based Violence through Rule of Law Projects. Washington DC: USAID. https://www.usaid.gov/sites/default/files/documents/1865/Toolkit_GBV\%20and\%20RoL_final_Web_14SEP10.pdf

Varma, D., Chandra, P., Thomas, T., \& Carey, M. (2007). Intimate Partner Violence and Sexual Coercion among Pregnant Women in India: Relationship with Depression and Post-Traumatic Stress Disorder. Journal of Affective Disorders, 102, 227-235. http://dx.doi.org/10.1016/j.jad.2006.09.026

World Health Organization (WHO) (2013). Global and Regional Estimates of Violence against Women: Prevalence and Health Effects of Intimate Partner Violence and Non-Partner Sexual Violence. Geneva: WHO. http://apps.who.int/iris/bitstream/10665/85239/1/9789241564625_eng.pdf?ua=1

World Health Organization (WHO) (2016). Violence against Women: Intimate Partner and Sexual Violence against Women. Fact Sheet No. 239, Updated January 2016. http://www.who.int/mediacentre/factsheets/fs239/en/

\section{Submit or recommend next manuscript to SCIRP and we will provide best service for you:}

Accepting pre-submission inquiries through Email, Facebook, Linkedin, Twitter, etc A wide selection of journals (inclusive of 9 subjects, more than 200 journals)

Providing a 24-hour high-quality service

User-friendly online submission system

Fair and swift peer-review system

Efficient typesetting and proofreading procedure

Display of the result of downloads and visits, as well as the number of cited articles

Maximum dissemination of your research work

Submit your manuscript at: http://papersubmission.scirp.org/ 